\title{
REDUCING UREA DEMAND FOR RICE CROP THROUGH FOLIAR APPLICATION OF UREA IN BORO SEASON
}

\author{
Ibrahim Hossain Manik ${ }^{1}$, Md. Anwarul Abedin ${ }^{{ }^{*}}$, Md. Rashedur Rahman ${ }^{2}$, Tusher \\ Chakrobarty $^{3}$, Sunain Bin Jaman ${ }^{1}$, Mahmud Al Noor ${ }^{3}$ and Razia Sultana ${ }^{4}$ \\ ${ }^{1}$ Department of Soil Science, ${ }^{2}$ Department of Agronomy, ${ }^{3}$ Department of Genetics and \\ Plant Breeding and ${ }^{4}$ Department of Seed Science and Technology, Faculty of Agriculture, \\ Bangladesh Agricultural University, Mymensingh-2202, Bangladesh
}

*Corresponding author: Md. Anwarul Abedin, E-mail: masumagricuture@gmail.com

\section{ARTICLE INFO ABSTRACT}

Received

12.02.2016

Accepted

18.04.2016

Online

30 April 2016

Key words

Urea,

Boro season,

BRRI dhan29,

Foliar application
This study was carried out with a view to evaluating the effect of foliar application of urea on BRRI dhan29. The experiment was laid out in a RCBD design with seven treatments ( $T_{1}$ : Full dose of prilled urea @ $140 \mathrm{Kg} \mathrm{N} \mathrm{ha}^{-1}$ ) (control), $T_{2}$ (50\% prilled urea +5 foliar spray @ $0.5 \% \mathrm{~N}$ solution @ $\left.5.5 \mathrm{~kg} \mathrm{~N} \mathrm{spray}^{-1}\right), \mathrm{T}_{3}(70 \%$ prilled urea +3 foliar spray @ $0.5 \% \mathrm{~N}$ solution @ $5.5 \mathrm{~kg} \mathrm{~N}$ spray $\left.^{-1}\right), \mathrm{T}_{4} \quad(50 \%$ prilled urea +3 foliar spray @ 1.0\% N solution @ 11 kg N spray $\left.{ }^{-1}\right), \mathrm{T}_{5}$ (50\% prilled urea +5 foliar spray @ $0.5 \% \mathrm{~N}$ solution @ $5.5 \mathrm{~kg} \mathrm{~N}$ spray $^{-1}+5 \mathrm{t} \mathrm{ha}^{-1}$ cow dung), $\mathrm{T}_{6}$ (70\% prilled urea +3 foliar spray @ $0.5 \% \mathrm{~N}$ solution @ $5.5 \mathrm{~kg} \mathrm{~N} \mathrm{spray}^{-1}+5 \mathrm{t} \mathrm{ha}^{-1}$ cow dung) and $\mathrm{T}_{7}(50 \%$ prilled urea + 3 foliar spray @ 1.0\% N solution @ $11 \mathrm{~kg} \mathrm{~N} \mathrm{spray}^{-1}+5 \mathrm{t} \mathrm{ha}^{-1}$ cow dung) and three replications. Soil and foliar application of nitrogen significantly influenced the growth and yield contributing characters like plant height, panicle length, and effective tillers hill ${ }^{-1}$ as well as the grain and straw yields of the crop. The treatment $T_{5}$ produced the highest grain yield $\left(6.68 \mathrm{t} \mathrm{ha}^{-1}\right)$ which was statistically similar to yield from $T_{7}, T_{6}$. Treatment $T_{2}, T_{3}$ and $T_{4}$ gave similar yield. The grain yields of these treatments were higher than those of $T_{1}$ treatment (soil application of urea only). The $T_{5}$ also produced the highest straw yield of the crop. The lowest grain yield of $4.72 \mathrm{t} \mathrm{ha}^{-1}$ and the lowest straw yield of $5.17 \mathrm{t} \mathrm{ha}^{-1}$ were recorded with $\mathrm{T}_{1}$ (control).

To cite this article: Manik IH, MA Abedin, MR Rahman, T Chakrobarty, SB Jaman, MA Noor and R Sultana, 2016. Reducing urea demand for rice crop through foliar application of urea in Boro season. Res. Agric. Livest. Fish. 3 (1): 79-85.

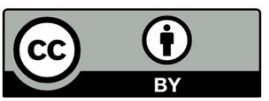

This is an open access article licensed under the terms of the Creative Commons Attribution 4.0 International License

www.agroaid-bd.org/ralf, E-mail: editor.ralf@gmail.com 


\section{INTRODUCTION}

Rice (Oryza sativa L.) is the most extensively cultivated cereal crop in Bangladesh. It plays an absolutely dominant role over all other crops in respect of economic and social significance. In Bangladesh agriculture it covers $75.8 \%$ of the total cropped area (BBS, 2007). Thus, it ranks the top position among the cereal crops grown in Bangladesh. In 2006-2007, 10.58 million hectares of land was under rice cultivation which produced 27.31 million tons of rice (BBS, 2007). The average yield of rice in Bangladesh is quite low (2.35 $\left.\mathrm{t} \mathrm{ha}^{-1}\right)$ compared to that in other leading rice growing countries such as China $\left(6.23 \mathrm{t} \mathrm{ha}^{-1}\right)$, Korea $\left(6.59 \mathrm{t} \mathrm{ha}^{-1}\right)$, Japan $\left(6.7 \mathrm{t} \mathrm{ha}^{-1}\right)$ and U.S.A. $\left(7.04 \mathrm{t} \mathrm{ha}^{-1}\right)$ (FAO, 2004).

Nitrogen is one of the major plant nutrients required for plant growth. For maximizing yield of rice, nitrogenous fertilizer is the kingpin in rice farming. Therefore, excessive nitrogen $(\mathrm{N})$ fertilization is one of the major concerns in sustainable agriculture for its decreased $\mathrm{N}$-utilization efficiency by crops and increased $\mathrm{N}$ release to the environment, resulting atmosphere and water systems pollution. The nitrogen use efficiency (NUE) in particular of urea fertilizer is very low (30-35\%) in the rice cropping system (IFDC, 2007). However, rice command area in Bangladesh is increasing. Many factors determine the fertilizer use efficiency for rice crop during cultivation such as soil, cultivar, season, environment, planting time, water management, weed control, cropping pattern, source, form, rate, time of application and method of application (Datta, 1978). Consequently, special types of $\mathrm{N}$ fertilizers have been developed for avoiding or at least reducing such losses. The special types of fertilizers so far marketed are foliar fertilizer, slow-release and controlled-release coated/encapsulated fertilizers. Besides developing special fertilizer types, various $\mathrm{N}$ management techniques like application of total $\mathrm{N}$ fertilizer in several splits in reference to the critical crop growth stages, deep placement of $\mathrm{N}$ fertilizer and foliar application are also recommended focusing the NUE of rice plants and finally maximizing rice yield. Recently foliar application of nutrients has become an important practice in the production of crops while application of fertilizers to the soil remains the basic method of feeding the majority of the crop plants. Therefore, the present investigation is undertaken to develop a suitable and sustainable reduced dose of $\mathrm{N}$ fertilization through foliar application for maximizing rice yield as well as minimizing $\mathrm{N}$ pollution to the environment.Foliar application refers to the spraying on leaves of growing plants with suitable fertilizer solutions. It is effective to the crops which are growing on waterlogged condition. In many cases aerial spray of nutrients is preferred and gives quicker and better results than the soil application (Jamal et al. 2006). In a previous study, it was noted that soil application of urea in recommended dose gave higher but statistically similar yield to foliar application of $2 \%$ urea solution, however, economic analysis showed that foliar application alone is not replaceable by soil application. In present study soil and foliar application of urea in different combinations was tested to see the effect of foliar application of urea in relation with soil application on the yield and yield contributing characters of BRRI dhan29 and to evaluate whether foliar application could replace the soil application of urea in boro rice cultivation.

\section{MATERIALS AND METHODS}

The experiment was conducted at Soil Science Field Laboratory of Bangladesh Agricultural University (BAU), Mymensingh during boro season from 22 January to 20 May 2015 under Non-Calcareous Dark Grey Floodplain Soil in the Old Brahmaputra Floodplain (AEZ 9). The experimental soil was silt loam, a member of Aerichaplaquept. The soil belongs to the Inceptisol order having only few horizons, developed under aquic moisture regime and variable temperature regimes. BRRI dhan29, a high yielding variety of rice was used as the test crop in this experiment. This variety was released for boro season by the Bangladesh Rice Research Institute (BRRI); Joydebpur, Gazipur in 1992 after regional and zonal trial and evaluation. The land was prepared thoroughly by ploughing and cross ploughing with a power tiller. Weeds and stubbles of the previous crop were collected and removed from the plot. After uniform labeling, the plots were laid out as per design of the experiment. The experiment was laid out in a randomized complete block design. The entire experimental area was divided into three blocks representing three replications to reduce soil heterogenic effects and each block was divided into seven unit plots with raised bunds as per treatments. Thus the total number of unit plots was 21 . The size of each unit plot was $4 \mathrm{~m} \times 2.5 \mathrm{~m}$. Plots were separated from one another by ails of $0.25 \mathrm{~m}$. Unit blocks were separated from one another by $1 \mathrm{~m}$ drain. Treatments were randomly distributed within the blocks. Forty days old seedlings were carefully uprooted from a seedling nursery and transplanted on well 
puddled unit plots. Three healthy seedlings were transplanted in each hill. Necessary irrigations were provided to the plots as and when required and water level was maintained at $5 \mathrm{~cm}$ on soil surface in each unit plot during the growing period of rice crop. The experiment plots were infested with some common weeds, which were removed by uprooting from the field three times during the crop growth. The crop was attacked by stem borer insect at the tillering stage. Therefore, insecticide (CURATERR) was applied in the crop field to control the pest. Crop was harvested at full maturity on 20 May 2015. After harvesting the crop each plot was bundled separately and brought to threshing floor. The crops were then threshed, cleaned and processed.

Five hills were randomly selected from each plot at maturity to record the yield contributing characters like plant height, panicle length, number of effective tillers hill ${ }^{-1}$, number of filled grains panicle ${ }^{-1}$ and 1000 -grain weight. The representative grain and straw samples were dried in an oven at $65^{\circ} \mathrm{C}$ for about 24 hours before they were ground by a grinding machine. The prepared samples were then stored in paper bags and finally kept into desiccators till analysis was done. For the determination of nitrogen $0.1 \mathrm{~g}$ of oven dry ground plant sample (grain or straw) was taken in a micro-kjeldahl flask. $1.1 \mathrm{~g}$ catalyst mixture $\left(\mathrm{K}_{2} \mathrm{SO}_{4}: \mathrm{CuSO}_{4} .5 \mathrm{H}_{2} \mathrm{O}: \mathrm{Se}=\right.$ 100:10:1), $3 \mathrm{ml} \mathrm{30 \%} \mathrm{H}_{2} \mathrm{O}_{2}$ and $5 \mathrm{ml} \mathrm{H}_{2} \mathrm{SO}_{4}$ were added into the flask. The flask was swirled and allowed to stand for about 10 minutes. Then heating was continued until the digest was clear and colorless. After cooling, the content was taken into a $100 \mathrm{ml}$ volumetric flask and the volume was made up to the mark with distilled water. A reagent blank was prepared in a similar manner. Total $\mathrm{N}$ content of plant sample was determined following Micro-Kjeldahl method. After completion of digestion $40 \% \mathrm{NaOH}$ was added with the digest for distillation. Finally the titration of distillate trapped in $\mathrm{H}_{3} \mathrm{BO}_{3}$ with $0.01 \mathrm{~N} \mathrm{H}_{2} \mathrm{SO}_{4}$ was done until the color changed from green to pink. After chemical analysis of grain and straw samples, the nitrogen content was calculated. Nitrogen uptakes were calculated from the following formula:

$$
\text { Nitrogen uptake }(\mathrm{kg} / \mathrm{ha})=\frac{\text { Nitrogencontent }(\%) \times \text { Yield }\left(\frac{\mathrm{kg}}{\mathrm{ha}}\right)}{100}
$$

Then, the collected data were analyzed statistically by F-test to examine the treatments effects and the mean differences were adjudged by Duncan's Multiple Range Test (DMRT) (Gomez and Gomez, 1984) and ranking was indicated by letters.

\section{RESULTS}

\section{Effect of urea application on yield contributing characters of BRRI dhan29}

The plant height of rice varied from $80.20 \mathrm{~cm}$ to $87.33 \mathrm{~cm}$ over the treatments (Table 1). The tallest plant was observed from treatment $T_{5}$ which was statistically similar to $T_{6}$ and $T_{7}$ treatment. The treatment $T_{6}$ had the smallest plant height. The treatments with respect to the plant height may be ranked as: $T_{5}>T_{7}>T_{6}>T_{4}>T_{2}>T_{1}>T_{3}$. The longest panicle was observed from $T_{5}$ which was statistically similar to $T_{6}$ and $T_{7}$ treatments. The shortest panicle length of $(20.63 \mathrm{~cm})$ was obtained from $T_{2}$ treatment. The treatments may be ranked in the order of $T_{5}>T_{7}>T_{6}>T_{1}>T_{4}>T_{2}>T_{3}$ in terms of decreasing panicle length. The panicle length and grain yield were positively correlated and statistically significant. The maximum number of effective tillers hill $^{-1}$ was found in $T_{5}$ which was statistically identical to $T_{4}, T_{6}$ and $T_{7}$ treatment (Table 1). The lowest number of effective tillers hill $^{-1}$ (9.40) was obtained in $T_{2}$ treatment. The treatments followed the order $T_{5}>T_{7}>T_{4}>T_{6}>$ $T_{3}>T_{1}>T_{2}$ in terms of effective tillers hill ${ }^{-1}$. The highest number of filled grains panicle ${ }^{-1}$ was found in $T_{5}$, which was statistically identical to $T_{6}$ and $T_{7}$ treatment. The lowest number of filled grains panicle ${ }^{-1}$ was found in $T_{3}$ treatment. The treatments followed the rank of $T_{5}>T_{7}>T_{6}>T_{1}>T_{4}>T_{2}>T_{3}$ with respect to grains panicle $e^{-1}$. The 1000 -grain weight of rice varied from 22.67 to 23.88 over the treatments. The highest value was noted in $\mathrm{T}_{2}$ treatment. The lowest value was noted in $\mathrm{T}_{1}$ treatment (Table 1).

\section{Effects of urea application on the yield of BRRI dhan29}

The grain yield ranged from $4.72 \mathrm{t} / \mathrm{ha}$ in $\mathrm{T}_{1}$ treatment to $6.68 \mathrm{t}$ ha ${ }^{-1}$ in $\mathrm{T}_{5}$ treatment (Table 2). Treatment $\mathrm{T}_{6}$ and treatment $T_{7}$ were statistically identical to $T_{5}$ with the grain yield of $6.14 \mathrm{t} \mathrm{ha}^{-1}$ and $6.37 \mathrm{t} \mathrm{ha}^{-1}$, respectively. The other treatments yield was almost same. The grain yields may be ranked in the order of $T_{5}>T_{7}>T_{6}>T_{3}>T_{4}>T_{2}>T_{1}$. The grain yield increase over control ranged from 0.42 to $41.32 \%$, where the highest yield increase was obtained in $T_{5}$ treatment and the lowest yield increased due to $T_{2}$ treatment (Table 2). The straw yield of rice was also significantly affected by the foliar application of nitrogen fertilizers. The straw yield of rice ranged from $5.170 \mathrm{t} \mathrm{ha}^{-1}$ to $6.963 \mathrm{t} \mathrm{ha}^{-1}$. The highest straw yield of $6.963 \mathrm{t} \mathrm{ha}^{-1}$ was observed in $\mathrm{T}_{5}$ 
treatment and the lowest yield of $5.170 \mathrm{t} \mathrm{ha}^{-1}$ in $\mathrm{T}_{1}$ treatment (Table 2). The straw yields obtained due to different treatment ranked in order of $T_{5}>T_{7}>T_{6}>T_{2}>T_{4}>T_{3}>T_{1}$.

Table1. Effects of treatments on yield contributing characters of BRRI dhan29

\begin{tabular}{|c|c|c|c|c|c|c|c|}
\hline Treatments & $\begin{array}{l}\text { Plant } \\
\text { height } \\
\text { (cm) }\end{array}$ & $\begin{array}{l}\text { Effectie } \\
\text { tillers hill }^{-1}\end{array}$ & $\begin{array}{l}\text { Non-effective } \\
\text { tillers hill }\end{array}$ & $\begin{array}{l}\text { Panicle } \\
\text { length } \\
\text { (cm) }\end{array}$ & $\begin{array}{l}\text { Filled } \\
\text { grains } \\
\text { panicle }^{-1}\end{array}$ & $\begin{array}{l}\text { Unfilled } \\
\text { grains } \\
\text { panicle }^{-1}\end{array}$ & $\begin{array}{l}\text { 1000-grain } \\
\text { weight (gm) }\end{array}$ \\
\hline $\mathrm{T}_{1}$ & $81.40 \mathrm{~b}$ & $10.33 \mathrm{bc}$ & 1.97 & $20.73 b$ & $135.5 \mathrm{bcd}$ & $16.57 \mathrm{a}$ & 22.62 \\
\hline $\mathrm{T}_{2}$ & $81.53 b$ & $9.40 \mathrm{C}$ & 2.26 & $20.63 b$ & $130.9 \mathrm{~cd}$ & $16.90 \mathrm{a}$ & 23.88 \\
\hline $\mathrm{T}_{3}$ & $80.20 \mathrm{~b}$ & $10.47 \mathrm{bc}$ & 2.33 & $21.00 \mathrm{~b}$ & $129.0 \quad d$ & $17.20 \mathrm{a}$ & 23.52 \\
\hline $\mathrm{T}_{4}$ & $81.67 \mathrm{~b}$ & $11.27 \mathrm{ab}$ & 2.07 & $20.70 \mathrm{~b}$ & $132.4 \mathrm{~cd}$ & $15.47 \mathrm{ab}$ & 23.73 \\
\hline $\mathrm{T}_{5}$ & $87.33 \mathrm{a}$ & $12.73 \mathrm{a}$ & 2.00 & $23.80 \mathrm{a}$ & $144.0 \quad \mathrm{a}$ & $16.27 \quad \mathrm{a}$ & 23.65 \\
\hline $\mathrm{T}_{6}$ & $83.47 \mathrm{ab}$ & $11.13 \mathrm{abc}$ & 2.23 & $22.57 \mathrm{ab}$ & $137.8 \mathrm{abc}$ & $14.50 \mathrm{~b}$ & 23.87 \\
\hline $\mathrm{T}_{7}$ & $83.75 a b$ & $11.40 \mathrm{ab}$ & 2.46 & $22.73 a b$ & $141.2 \mathrm{ab}$ & $14.37 \mathrm{~b}$ & 23.52 \\
\hline $\operatorname{LSD}_{0.05}$ & 4.07 & 1.61 & 0.48 & 2.03 & 6.89 & 1.71 & 1.08 \\
\hline $\operatorname{SE}( \pm)$ & 1.32 & 0.52 & 0.15 & 0.66 & 2.24 & 0.55 & 0.35 \\
\hline $\begin{array}{l}\text { Level of } \\
\text { significane }\end{array}$ & * & * & NS & * & ** & * & NS \\
\hline CV (\%) & 2.77 & 8.30 & 12.29 & 5.27 & 2.85 & 6.04 & 2.58 \\
\hline
\end{tabular}

Table 2. Effects of treatments on yield of BRRI dhan29

\begin{tabular}{|c|c|c|c|c|c|}
\hline Treatments & $\begin{array}{l}\text { Grain yield } \\
\left(\mathrm{t} \mathrm{ha}^{-1}\right)\end{array}$ & $\begin{array}{l}\text { \% Increase } \\
\text { over control }\end{array}$ & $\begin{array}{l}\text { Straw yield } \\
\left(\mathrm{t} \mathrm{ha}^{-1}\right)\end{array}$ & $\begin{array}{l}\text { Biological yield } \\
\left(\mathrm{t} \mathrm{ha}^{-1}\right)\end{array}$ & Harvest index (\%) \\
\hline $\mathrm{T}_{1}$ & $4.72 \mathrm{~b}$ & - & $5.17 \quad b$ & $9.887 \mathrm{~b}$ & $47.74 \mathrm{ab}$ \\
\hline $\mathrm{T}_{2}$ & $4.74 \quad b$ & 0.42 & $5.36 \mathrm{~b}$ & $10.11 b$ & $46.95 \mathrm{~b}$ \\
\hline $\mathrm{T}_{3}$ & $4.85 \mathrm{~b}$ & 2.60 & $5.17 b$ & $10.01 \mathrm{~b}$ & $48.40 \mathrm{a}$ \\
\hline $\mathrm{T}_{4}$ & $4.85 \mathrm{~b}$ & 2.60 & $5.20 \mathrm{~b}$ & $10.05 \mathrm{~b}$ & $48.22 \mathrm{ab}$ \\
\hline $\mathrm{T}_{5}$ & $6.68 \mathrm{a}$ & 41.32 & $6.96 \mathrm{a}$ & $13.64 \mathrm{a}$ & $48.97 \mathrm{a}$ \\
\hline $\mathrm{T}_{6}$ & $6.14 \mathrm{a}$ & 29.89 & $6.68 \mathrm{a}$ & $12.81 \mathrm{a}$ & $47.89 a b$ \\
\hline $\mathrm{T}_{7}$ & $6.37 \mathrm{a}$ & 34.91 & $6.69 \mathrm{a}$ & $13.07 \mathrm{a}$ & 48.77 a \\
\hline $\mathrm{LSD}_{0.05}$ & 0.73 & - & 0.86 & 1.11 & 1.16 \\
\hline $\operatorname{SE}( \pm)$ & 0.23 & - & 0.28 & 0.35 & 0.38 \\
\hline $\begin{array}{l}\text { Level of } \\
\text { significance }\end{array}$ & ** & - & $\star *$ & ** & * \\
\hline CV (\%) & 7.52 & - & 8.25 & 5.47 & 1.38 \\
\hline
\end{tabular}

\section{Nitrogen content in rice grain}

The results of nitrogen uptake by grain and straw of BRRI dhan29 has been calculated from the yield and $\mathrm{N}$ concentrations data of rice. Different combinations of soil and foliar application of $\mathrm{N}$ fertilizer significantly influenced the $\mathrm{N}$ uptake by rice grain and straw (Table 3). The $\mathrm{N}$ uptake by rice grain varied from 38.26 to $74.89 \mathrm{~kg} \mathrm{ha}{ }^{-1}$. The highest $\mathrm{N}$ uptake by grain was observed in $\mathrm{T}_{7}$ treatment and the lowest $\mathrm{N}$ uptake was recorded in $T_{1}$ treatment. The $\mathrm{N}$ uptake by rice grain in treatment $\mathrm{T}_{7}$ was not statistically identical with other treatments. The $\mathrm{N}$ uptake by rice grain in $\mathrm{T}_{1}$ treatment was statistically identical to found in treatment $T_{2}$. The $T_{4}, T_{5}$ and $T_{6}$ treatments gave medium $N$ uptake. The treatments followed the rank of $T_{7}>T_{6}>T_{5}>T_{4}>T_{3}>T_{2}>T_{1}$ with respect to $\mathrm{N}$ uptake by grain.

\section{Nitrogen content in straw}

The nitrogen concentration in the straw ranged from $0.446 \%$ in $\mathrm{T}_{4}$ treatment to $0.560 \%$ in $\mathrm{T}_{6}$ treatment. The highest $\mathrm{N}$ concentration recorded in $\mathrm{T}_{6}$ treatment was statistically identical to those found in $\mathrm{T}_{7}$ treatment. The $\mathrm{N}$ concentration in straw found in $\mathrm{T}_{5}$ treatment was statistically identical to those found in $T_{1}, T_{2}$ and $T_{3}$ treatments. The $\mathrm{T}_{4}$ treatment recorded the lowest straw $\mathrm{N}$ content (Table 3). 
Table 3. Effects of foliar application of urea on nitrogen concentration of BRRI dhan29

\begin{tabular}{|lll|}
\hline Treatments & \multicolumn{2}{c|}{$\% \mathbf{N}$} \\
\cline { 2 - 3 } & Grain & Straw \\
\hline $\mathrm{T}_{1}$ & $0.81 \mathrm{~b}$ & $0.47 \mathrm{bc}$ \\
$\mathrm{T}_{2}$ & $0.81 \mathrm{~b}$ & $0.47 \mathrm{bc}$ \\
$\mathrm{T}_{3}$ & $0.81 \mathrm{~b}$ & $0.47 \mathrm{bc}$ \\
$\mathrm{T}_{4}$ & $0.89 \mathrm{~b}$ & $0.44 \mathrm{c}$ \\
$\mathrm{T}_{5}$ & $1.08 \mathrm{a}$ & $0.50 \mathrm{bc}$ \\
$\mathrm{T}_{6}$ & $1.17 \mathrm{a}$ & $0.56 \mathrm{a}$ \\
$\mathrm{T}_{7}$ & $1.17 \mathrm{a}$ & $0.53 \mathrm{ab}$ \\
LSD & 0.05 \\
$\mathrm{SE}( \pm)$ & 0.13 & 0.02 \\
Level of significance & 0.04 & $*$ \\
CV $(\%)$ & $* *$ & 7.51 \\
\hline
\end{tabular}

\section{Nitrogen uptake by grain}

The results of nitrogen uptake by grain and straw of BRRI dhan29 has been calculated from the yield and $\mathrm{N}$ concentrations data of rice (Figure 1). Different combinations of soil and foliar application of $\mathrm{N}$ fertilizer significantly influenced the $\mathrm{N}$ uptake by rice grain and straw (Figure 1). The $\mathrm{N}$ uptake by rice grain varied from 38.26 to $74.89 \mathrm{~kg} \mathrm{ha}^{-1}$. The highest $\mathrm{N}$ uptake by grain was observed in $\mathrm{T}_{7}$ treatment and the lowest $\mathrm{N}$ uptake was recorded in $T_{1}$ treatment. The $N$ uptake by rice grain in treatment $T_{7}$ was not statistically identical with other treatments. The $\mathrm{N}$ uptake by rice grain in $\mathrm{T}_{1}$ treatment was statistically identical to found in treatment $\mathrm{T}_{2}$. The $T_{4}, T_{5}$ and $T_{6}$ treatments gave medium $\mathrm{N}$ uptake. The treatments followed the rank of $T_{7}>T_{6}>T_{5}>T_{4}>T_{3}>T_{2}>T_{1}$ with respect to $N$ uptake by grain (Figure 1).

\section{Nitrogen uptake by straw}

The $\mathrm{N}$ uptake by rice straw ranged from 23.00 to $35.46 \mathrm{~kg} \mathrm{ha}^{-1}$ (Figure 1). The highest nitrogen uptake by straw $35.46 \mathrm{~kg} \mathrm{ha}^{-1}$ was observed in $\mathrm{T}_{7}$ treatment and the lowest $\mathrm{N}$ uptake by straw $23.00 \mathrm{~kg} \mathrm{ha}^{-1}$ was observed in $T_{2}$ treatment. The $\mathrm{N}$ uptake by straw in the treatment $T_{7}$ was statistically identical with $T_{5}$ treatment. $T_{4}$ is identical with $T_{1}$ treatments. The nitrogen uptake by straw in the treatment $T_{6}$ is medium. The treatments followed the rank of $T_{7}>T_{5}>T_{3}>T_{6}>T_{4}>T_{1}>T_{2}$, with respect to $N$ uptake by straw (Figure 1).

\section{Total nitrogen uptake}

The total $\mathrm{N}$ uptake by rice (sum of grain and straw) was influenced significantly by different treatments (Figure 1). The highest total $\mathrm{N}$ uptake $\left(110.3 \mathrm{~kg} \mathrm{ha}^{-1}\right)$ was observed in $\mathrm{T}_{7}$ and the lowest $\mathrm{N}$ uptake $(62.81 \mathrm{~kg}$ $\mathrm{ha}^{-1}$ ) was observed in $\mathrm{T}_{1}$ treatment. The total $\mathrm{N}$ uptake by rice due to different treatments followed the order: $T_{7}>T_{5}>T_{6}>T_{3}>T_{4}>T_{2}>T_{1}$ (Figure 1).

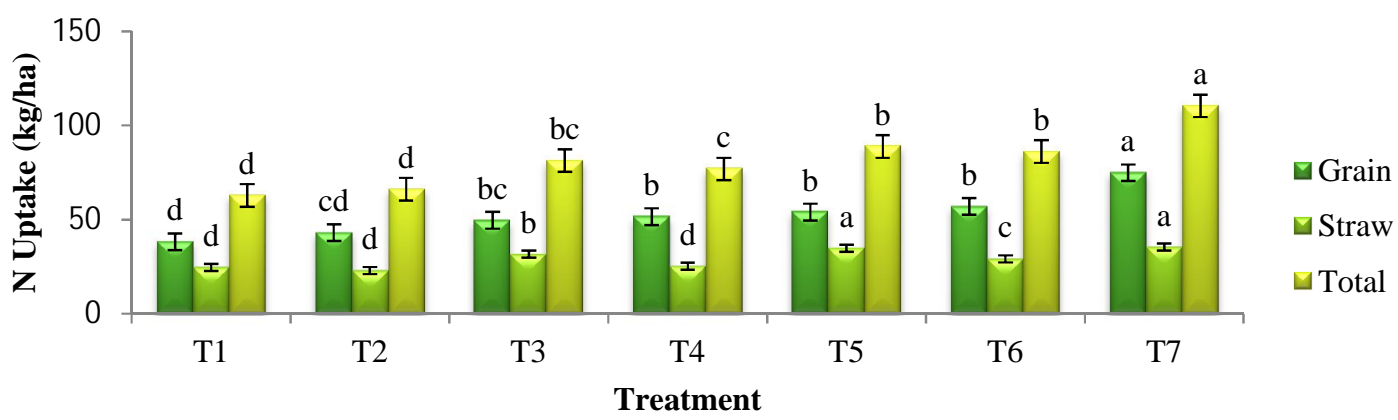

Figure 1. Effects of foliar application of urea on nitrogen uptake by BRRI dhan29 Economic analysis 
The economic performance of different treatments was evaluated through economic analysis (Figure 2). The analysis showed that the highest gross return (Tk. 141120) was obtained from $T_{5}$ and the lowest one (Tk. 100470) was obtained from $T_{1}$ treatment. The analysis also showed that the highest variable cost was recorded in $T_{6}$ (Tk. 10084) and lowest one was obtained from treatment $T_{4}$ (Tk. 5384). Gross margin also varied due to different treatments. The highest gross margin was obtained (Tk. 133085) from $T_{5}$ treatment and the lowest one (Tk. 95066) was obtained from $\mathrm{T}_{1}$ treatment. From the economic analysis the highest marginal gross margin was obtained (Tk. 38019) from $T_{5}$ treatment and lowest one was obtained from $T_{2}$ (Tk. 778).

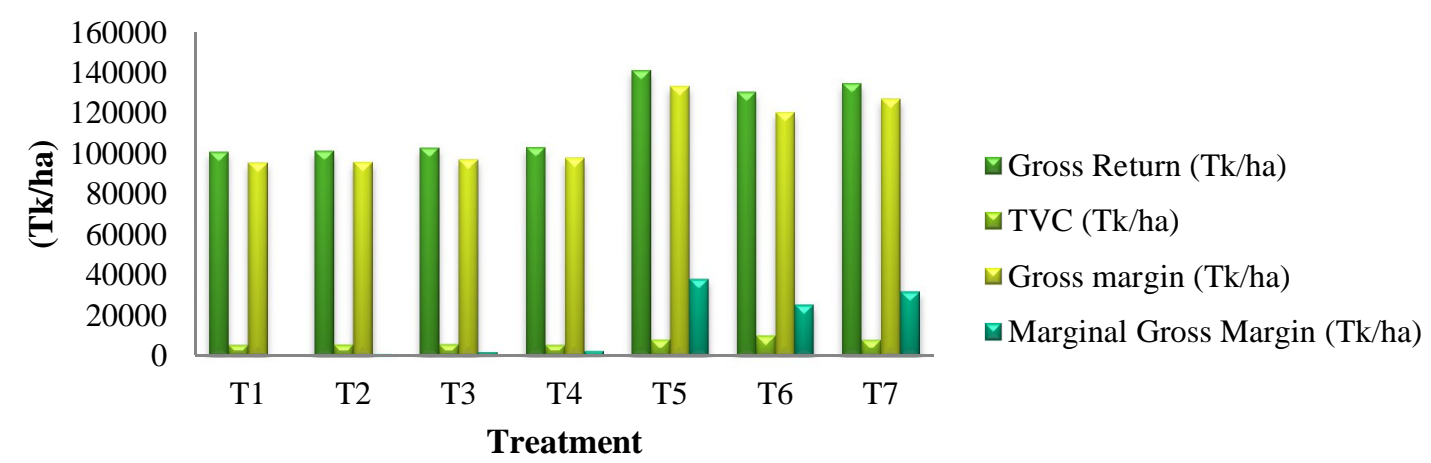

Figure 2. Economic analysis of Treatments over BRRI Dhan29

\section{DISCUSSION}

The nitrogen use efficiency especially from urea fertilizer is very low (30-35\%) in rice cultivation due to loss of applied $\mathrm{N}$ through a number of processes including volatilization, denitrification, run-off, leaching and fixation. Many strategies have been developed to increase the efficiency of applied fertilizers through proper timing, deep placement, foliar application, modified forms of fertilizers, irrigation control etc. Among them foliar application of $\mathrm{N}$ introduces a new dimension in the $\mathrm{N}$ fertilization regime. But, foliar application of $\mathrm{N}$ has been found to have negative, similar or positive effect on yield of rice which is still a researchable topic. The present study was conducted to evaluate the effects of broadcast and foliar application of $\mathrm{N}$ fertilizers in comparison with broadcast application of prilled urea alone on $\mathrm{N}$ use efficiency and yield of boro rice. The results revealed that foliar application of $\mathrm{N}$ was more effective than broadcast application of PU alone.

The grain yield of BRRI dhan29 has been significantly increased due to foliar application of $\mathrm{N}$ fertilizers. There were numerical variations in grain yield among the treatments. The highest grain yield was recorded for $\mathrm{T}_{5}(50 \%$ prilled urea +5 foliar spray @ $0.5 \% \mathrm{~N}$ solution/ha i.e. $5.5 \mathrm{~kg} \mathrm{~N} / \mathrm{spray}+5 \mathrm{t} / \mathrm{ha}$ cow dung) which was identical to $\mathrm{T}_{6}(70 \%$ prilled urea +3 foliar spray @ $0.5 \% \mathrm{~N}$ solution $/ \mathrm{ha}$ i.e. $5.5 \mathrm{~kg} \mathrm{~N} / \mathrm{spray}+5 \mathrm{t} / \mathrm{ha}$ cow dung) and $\mathrm{T}_{7}(50 \%$ prilled urea +3 foliar spray @ $1.0 \% \mathrm{~N}$ solution/ha i.e. $11 \mathrm{~kg} \mathrm{~N} / \mathrm{spray}+5 \mathrm{t} / \mathrm{ha}$ cow dung). These results indicate positive effects of foliar application of $\mathrm{N}$ fertilizers on rice yield. The increase in rice yield as observed in the present study is due to the direct supply of nitrogen from foliar spray throughout the growing period of rice and due to minimum loss of nitrogen as because of foliar application. These findings are well corroborated with Rahman (2010) who observed increased rice yield due to foliar application of nitrogen. Another findings Shaila (2009) showed negative effect of foliar application where soil application is not replaceable by foliar application.

The $\mathrm{N}$ uptake and recovery of applied $\mathrm{N}$ by rice were increased due to foliar application combined with broadcasting of prilled urea. However, the broadcast application of $\mathrm{N}$ in the form of PU demonstrated lower uptake of $\mathrm{N}$ and recovery of added $\mathrm{N}$ by rice. The nitrogen use efficiency by rice was high with foliar application treated plots than PU treated ones. These results clearly indicate that the foliar application of $\mathrm{N}$ minimizes the loss of $\mathrm{N}$ that results in higher $\mathrm{N}$ use efficiency and increased grain yield of rice as compared to broadcast application of $\mathrm{N}$ in the form of prilled urea. 


\section{CONCLUSION}

The overall results indicated that $T_{5}$ treatment gave the highest yield. Treatments $T_{6}$ and $T_{7}$ gave a statistically comparable yield with treatment $T_{5}$. The treatments $T_{1}, T_{2}, T_{3}$ and $T_{4}$ gave medium yield and the values were statistically similar to each others. The treatment $T_{5}, T_{6}$ and $T_{7}$ could be alternative of soil application alone. In these treatments marginal gross margin is higher than $T_{1}$ treatment. From the above discussion we can say that treatment $T_{5}, T_{6}$ and $T_{7}$ is better treatments in terms of obtaining higher grain yield than $T_{1}$ treatment. The effect of $T_{5}$ treatment was specially remarkable for achieving higher yield of BRRI dhan29 and in the economic point of view. The best treatment ranking: $T_{5}>T_{7}>T_{6}$. It can be concluded that, soil application of urea is replaceable by soil application of $50 \%$ urea coupled with 5 foliar application of urea and 5 t/ha cow dung. However, further research on different locations of Bangladesh is needed for making final recommendation.

\section{ACKNOWLEDGEMENTS}

Author is grateful to the Ministry of Science and Technology, Government of the People's Republic of Bangladesh for the assignation of National Science and Technology fellowship which has partly supported the research work.

\section{REFERENCES}

1. BBS (Bangladesh Bureau of Statistics), 2007. Statistical Year Book of Bangladesh. Statistics Division, Ministry of Planning, Govt. People's Republic of Bangladesh, Dhaka.

2. Datta SK, 1978. Fertilizer management for efficient use in wetland rice soils. In Soil and Rice. International Rice Research Institute, Los Banos, Philippines. pp. 671-670.

3. FAO 2004. Food and Agriculture Organization of the United Nations, Production 11 Yearbook 46FAO, Rome, Italy.

4. Gomez KA and Gomez AA (Editiors), 1984. Statistical Procedures for Agricultural Research. An international rice research institute book. JOHN WILEY \& SONS, New York, United States. pp 58-59.

5. IFDC (International Fertilizer Development Centre) 2007. Mitigating poverty and environmental degradation through nutrient management in South Asia IFDC Report, March 2007.

6. Jamal Z, Hamyadan M, Ahmed N and Fayyaz M, 2006. Effect of soil and foliar application of different concentration of NPK and foliar application of $\mathrm{NH}_{4}$ on different parameters in wheat. Journal of Agronomy, 5: 251-256.

7. Rahman MW, 2010. Effect of soil and foliar application of urea in boro rice to different $\mathrm{N}$ levels. MS Thesis, Department of Soil Science, Bangladesh Agricultural University, Mymensingh-2202.

8. Shaila SA, 2009. Soil and foliar application of urea in boro rice to different $\mathrm{N}$ levels. MS Thesis, Department of Soil Science, Bangladesh Agricultural University, Mymensingh-2202. 